\title{
Treaties over Time and Human Rights: A Case Law Analysis of the Inter-American Court of Human Rights
}

Fecha de recepción: 17 de febrero de 2015

Fecha de aceptación: 9 de agosto de 2016

Doi: 10.12804/revistas.urosario.edu.co/acdi/a.5290

\section{Carlos Enrique Arévalo Narváez and Paola Andrea Patarroyo Ramírez ${ }^{* *}$}

Abstract: This paper analyzes the issue of treaties over time and the interpretations of the Inter-American Court of Human Rights in this context. Parts 1 and 2 introduce the elements of treaty interpretation in general international law, providing criteria for the application of the evolutionary approach to treaty interpretation, the debate between the application of evolutive interpretation and the use of subsequent conduct. Part 3 addresses the issue of fragmentation in international human rights law, and through the case law of the Inter-American Court of Human Rights,

* Professor of International Law and Human Rights at the Universidad de La Sabana (Colombia). Master of Law in International Legal Studies from NYU, and Institute for International Law and Justice Fellow at the UN's International Law Commission. Member of the Universidad de La Sabana Research Group on International Law and Human Rights. Former Auxiliary Justice of the Constitutional Court of Colombia. E-mail: carlos. arevalo1@unisabana.edu.co

** Bachelor of Laws, Universidad de La Sabana (Colombia). Advanced Studies in Social, Political, and Economic Sciences, University of Notre Dame. Member of the Universidad de La Sabana Research Group on International Law and Human Rights. Former Legal Advisor, Treaty Division, Colombian Ministry of Foreign Affairs. E-mail: p.patarroyo@, gmail.com

Para citar este artículo: Arévalo Narváez, C. E. \& Patarroyo Ramírez, P. A., "Treaties over Time and Human Rights: A Case Law Analysis of the Inter-American Court of Human Rights”, Anuario Colombiano de Derecho Internacional (ACDI), 2017, 10, pp. 295-331. Doi: 10.12804/revistas.urosario.edu.co/acdi/a.5290 
provides evidence for the application of the rules of general international law to interpret the American Convention on Human Rights. Finally, conclusions are extracted on the basis of the case law analyzed, contrasting the Court's application of the American Convention over time, the conclusions of the International Law Commission Reports on the Fragmentation of International Law in 2008, and the preliminary conclusions of the Study Group on Subsequent Agreements and Subsequent Practice concerning treaty interpretation and the issue of the passage of time.

Key words: Treaty interpretation, treaties over time, human rights, InterAmerican Court of Human Rights, subsequent agreements.

Los tratados en el tiempo y los derechos humanos: un análisis desde la jurisprudencia de la Corte Interamericana de Derechos Humanos

Resumen: el presente escrito analiza la cuestión de los tratados en el tiempo en el marco del alcance que la Corte Interamericana de Derechos Humanos le ha dado al ejercicio interpretativo de los convenios sobre las materias propias de su jurisdicción. Las partes 1 y 2 introducen los elementos esenciales de la interpretación de los tratados en el derecho internacional general, proporcionando elementos para la aplicación de la aproximación evolutiva como una herramienta hermenéutica, planteando, así mismo, el aparente debate que existe entre dicha aproximación y el uso de la conducta subsiguiente como criterios interpretativos. La parte 3 estudia el impacto del fenómeno de la fragmentación en el derecho internacional de los derechos humanos, evidenciando, a través de la jurisprudencia de la Corte Interamericana de Derechos Humanos, la aplicación de reglas del derecho internacional general para interpretar la Convención Americana sobre Derechos Humanos. Finalmente, se arriba a conclusiones sobre la interpretación en el tiempo de los tratados en materia de derechos humanos, como resultado del contraste entre la aplicación intertemporal que la Corte ha hecho de la Convención Americana, el Reporte sobre Fragmentación de la Comisión de Derecho Internacional en 2008 y los hallazgos preliminares del Grupo de Estudio sobre Acuerdos y Prácticas Subsiguientes respecto de la interpretación de tratados y el asunto del paso del tiempo. 
Palabras clave: interpretación de tratados, tratados en el tiempo, derechos humanos, Corte Interamericana de Derechos Humanos, acuerdos subsiguientes.

Os tratados no tempo e os Direitos Humanos: Uma análise desde a Jurisprudência da Corte Interamericana de Direitos Humanos

Resumo: $\mathrm{O}$ presente escrito analisa a questão dos tratados no tempo no marco do alcance que a Corte Interamericana de Direitos Humanos lhe tem dado ao exercício interpretativo dos Convênios sobre as matérias próprias da sua jurisdição. As Partes 1 e 2 introduzem os elementos essenciais da interpretação dos tratados no direito internacional geral, proporcionando elementos para a aplicação da aproximação evolutiva como uma ferramenta hermenêutica, expondo assim mesmo, o aparente debate que existe entre dita aproximação e o uso da conduta subsequente como critérios interpretativos; A parte 3 estuda o impacto do fenómeno da fragmentação no direito internacional dos direitos humanos, evidenciando, através da jurisprudência da Corte Interamericana de Direitos Humanos, a aplicação de regras do direito internacional geral para interpretar a Convenção Americana sobre Direitos Humanos. Finalmente, chega-se a conclusões sobre a interpretação no tempo dos tratados em matéria de direitos humanos, como resultado do contraste entre a aplicação intertemporal que a Corte tem feito da Convenção Americana, o Reporte sobre Fragmentação da Comissão de Direito Internacional em 2008, e os achados preliminares do Grupo de Estudo sobre Acordos e Práticas Subsequentes respeito da interpretação de tratados e o assunto do passo do tempo.

Palavras-chave: Interpretação de tratados, tratados no tempo, direito humanos, Corte Interamericana de Direitos Humanos, acordos subsequentes.

\section{Introduction}

When applying the necessary abstract rule of law to the concrete case, they (international tribunals) create the legal rule for the individual case before them. The actual operation of law in society is a process of gradual crystallization of the abstract legal rule, beginning with the Constitution 


\section{of the State, as the most fundamental and abstract body of rules and ending with the concrete shaping of the individual legal relation.}

\section{H. LAUTERPACHT ${ }^{1}$}

The principle of pacta sunt servanda as one of the cornerstones of international treaty law implies that agreements must be kept. No matter how clearly constructed treaty provisions are, there will be a need for further concretizing: "Rules which originally appear to be sufficiently clear, may turn out to be ambiguous in the light of unanticipated cases or circumstances". ${ }^{2}$

Far from being static, treaties are dynamic legal instruments. Between the search for stability in the application of the provisions over time, the pursuit of the treaty's object and purpose under changing circumstances and subsequent developments, difficulties arise as a consequence of the absence of a centralized legislative power in international law. This is compounded by the lack of an established hierarchy among international legal instruments. It is precisely in the gaps between sources of international law, particularly in the application of treaty and customary law, ${ }^{3}$ such as the Vienna Convention on the Law of Treaties (hereinafter VCLT), where the issue of treaties over time centers its discussion.

This issue has been subject of analysis in contemporary international law from several perspectives. In 2006, the International Law Commission (hereinafter ILC) concluded its Report on the Fragmentation of International Law, which included an analysis of the rules of treaty interpretation, suggesting differential application of varied means of interpretation in "self-contained regimes". Meanwhile, the ILC has studied subsequent practice since 2008 under the direction of Professor Georg Nolte, ${ }^{4}$ currently

1 Lauterpacht, H., The Function of Law in the International Community, Oxford University Press, 1933, p. 263.

2 Thirlway, H. W. A., International Customary Law and Codification, Sijthoff, Leiden, 1972, pp. 125-146. As in: International Law Commission, Sixty-second Session (2010), ILC(LXII)SG/ TOT/INFORMAL/1, p. 1. Introductory report presented by Nolte, G. to the Study Groups on Treaties over Time, Jurisprudence of the International Court of Justice and arbitral tribunals of ad hoc jurisdiction relating the subsequent agreements and the subsequent practice (hereinafter Introductory Report 2010).

3 Ibid., para. 3.

4 Ibid., Annex A, pp. 365-389 (hereinafter Annex A). 
focused on "Subsequent Agreement and Practice in relation to interpretation of treaties", and has reached some relevant conclusions. ${ }^{5}$

In the arena of international adjudication, tribunals have applied varied rules of interpretation to address the effect of the passage of time over treaty provisions. The application of International Human Rights treaties over time poses an additional challenge for the judiciary. The emergence of unforeseen factual scenarios different from those acknowledged when the treaty was drafted, and the expansion of norms concerning certain guarantees, paired with the need for protection of individual and collective rights, have implied approaches beyond the VCLT rules of interpretation. The Inter-American Court of Human Rights (hereinafter IACTHR) has included in its jurisprudence several approaches to treaty interpretation that contrast the approach suggested by the ILC conclusions concerning treaty interpretation in self-contained regimes, and resemble general international law's rules of interpretation for the protection of fundamental rights and guarantees.

\section{General rules of treaty interpretation}

As international law is based on varied sources of diverse origin, treaties constitute a means of creating and modifying existing norms. The multiplicity of parties and subjects implies challenges and several criteria for interpretation, a scenario in which the possibility of fragmentation has been suggested. ${ }^{6}$

Treaty interpretation has been classically conceived as "a single combined operation, which places appropriate emphasis on the various means of interpretation indicated, respectively, in articles 31 and 32". ${ }^{7}$ These VCLT rules provide general principles as a starting point for interpretation, including good faith, the need to analyze ordinary meanings, ${ }^{8}$ and context,

5 Yearbook of the International Law Commission, 2013, UN Doc. A/68/10. A. Chapter IV. Subsequent agreements and subsequent practice in relation to the interpretation of treaties.

6 Greenwood, S., "Unity and diversity in international law", in Andenas, M. \& Bjorge, E., A Farewell to Fragmentation, Cambridge University Press, 2015, p. 42.

Yearbook of the International Law Commission, 2013, UN Doc. A/68/10. A. Chapter IV. Subsequent agreements and subsequent practice in relation to the interpretation of treaties. Conclusion 1, p. 11. Vienna Convention on the Law of Treaties, 1155 UNTs 331, 8 ILM 679. Yearbook of the International Law Commission, 1966, vol. II, pp. 218-223, para. 8.

8 Young Loan Arbitration (Belgium, France, Switzerland, United Kingdom and United States/Germany) 59 ILR 494 (1980). 
object, and purpose. ${ }^{9}$ At the time when such rules were introduced during the negotiation of the VCLT, a scholarly sector considered it dangerous that the interpreter could approach such a task with his or her mind partly made up rather than open to all evidence that may be brought, ${ }^{10}$ a notion that misconceived the function of interpretation. ${ }^{11}$

Recognizing the relevance of the textual interpretation of a treaty, ${ }^{12}$ the traditional notion of interpretation has a wider approach — without regard for the textual, subjective, or teleological nature of the method used $-{ }^{13}$ which will always imply going beyond the principle or doctrine stated in the treaty. ${ }^{14}$ The need to concretize treaties implies consideration of all the concomitant circumstances of the case at hand, to obtain a result "to effectuate the larger general purpose which the parties desired the treaty to serve". ${ }^{15}$

Before analyzing the phenomena related to treaties over time in the IACTHR we will elaborate on the following means of interpretation: i) "Subsequent practice and agreement" contained in article 31 (3) (a) (b) of the VCLT, ${ }^{16}$ ii) "evolutive interpretation" framed in the jurisprudence of international tribunals, and iii) the principle of "systematic integration" covered by article 31 (3) (c).

9 Fox, H., "Article 31 (3) (a) and (b) of the Vienna Convention and the Kasikili/Sedulu Island Case", in Fitzmaurice, M., Treaty Interpretation and the Vienna Convention on the Law of Treaties, p. 63.

Haraszti, G. Some Fundamental Problems in the Law of Treaties, Akadémiai Kiadó, Budapest, 1973, p. 18.

10 Yearbook of the International Law Commission, 1964, vol. II, UN Doc. A/CN.4/167 and Add.1-3, p. 53.

11 See Harvard Law School, Research in International IMW, part III. Law of Treaties, article 19, p. 946.

12 Sinclair, I., The Vienna Convention on the Law of Treaties, Manchester University Press, 1984, p. 115.

13 See Annuaire de l'hnstitute de droit international, 1956, vol. 46, p. 356 and Yearbook of the International Law Commission, 1966, vol. II, p. 218.

14 Beagle Channel Arbitration (Argentina v. Chile) (1977), ILR 52: 93, para. 127.

15 Yearbook of the International Law Commission, 1964, vol. II, UN Doc. A/CN.4/167 and Add.1-3, p. 53. Also see, Harvard Law School, p. 946.

16 Introductory Report 2010, supra note 4, p. 2. "Subsequent agreements and subsequent practice are included by article 31 (3) (a) and (b) of the Vienna Convention on the Law of the Treaties $[\ldots]$ ". 


\section{Means of interpretation}

\section{1. "Subsequent conduct": a joint "subsequent agreement" and "subsequent practice"}

Subsequent agreements and practice are forms by which, after the conclusion of a treaty, the parties present a consistent and systematic way of understanding and applying the treaty or its provisions, in such a way that it becomes relevant. ${ }^{17}$ These rules, contained in article 31 of the VCLT, follow a line of reasoning developed in Air Transport Arbitration Award (USA v. France $)^{18}$ and in the 1962 Case concerning the Temple of Prêab Vibéar. In such cases, the conduct of the Parties at the time when their first differences arose upon the application of an Agreement are "a possible source of a subsequent modification, arising out of certain actions or certain attitudes, having a bearing on the juridical situation of the Parties and on the rights that each of them could properly claim". ${ }^{19}$

Article 31 distinguishes between subsequent agreement —article 31 (3) (a) — and subsequent practice — article 31 (3) (b) -.${ }^{20}$ The ILC has defined the former as "an agreement between the parties, reached after the conclusion of a treaty, regarding the interpretation of the treaty or the application of its provisions". ${ }^{21}$ Subsequent practice is the conduct in the application of the treaty attributable to a State Party after its conclusion, which "constitutes objective evidence of the understanding of the parties

17 See Introductory Report 2010, supra note 4, p. 2, and Gardiner, R., Treaty Interpretation, Oxford University Press, Oxford, 2008, p. 226.

18 It is important to underline that the president of this tribunal was Mr. Roberto Ago, prominent member of the ILC from 1957 to 1978 and Special Rapporteur on State Responsibility from 1963 to 1980 . He was elected Judge of the ICJ in 1979, but was allowed to present his final report before the ICJ in 1980, maintaining the status of Rapporteur until that date.

19 Air Transport Arbitration Award (USA v. France) of 22 December 1963, UNRIAA, vol. XVI, pp. 62, 63, footnote 1. Case concerning the Temple of Prêah Vihéar (Cambodia v. Thailand), Judgment of 15 June 1962, ICJ Reports 1962, p. 33.

20 Yearbook of the International Law Commission, 1966, vol. II, UN Doc A/CN.4/L.117 and Add. 1, p. 221 (hereinafter Yearbook 1966). Commentaries to the VCLT.

21 Yearbook of the International Law Commission, 2013, UN Doc. A/68/102013. A. Chapter IV. Subsequent agreements and subsequent practice in relation to the interpretation of treaties. Conclusion 4. 
as to the meaning of the treaty". ${ }^{22}$ In terms of the ILC "[it] consists of conduct in the application of a treaty, after its conclusion, which establishes the agreement of the parties regarding the interpretation of the treaty". ${ }^{23}$

In 2010 professor Nolte proposed to address "subsequent agreement" and "subsequent practice" jointly, using the term "subsequent conduct". ${ }^{24}$ The ILC finally distinguished the value of both terms stating that a "subsequent agreement between the parties regarding the interpretation of the treaty or the application of its provisions" ipso facto has the effect of constituting an authentic interpretation of the treaty, whereas a subsequent practice only has this effect if it "shows the common understanding of the parties as to the meaning of the terms". ${ }^{25}$

Both phenomena constitute "objective evidence of the understanding of the parties as to the meaning of the treaty", 26 and may contribute to a clarification of its meaning, narrowing the possible meanings of a term or the treaty as a whole or confirming a wider interpretation or a certain scope for the exercise of discretion by the parties. ${ }^{27}$ With the passage of time, "[they] may assist in determining whether or not the presumed intention of the parties upon the conclusion of the treaty was to give a term used a meaning that is capable of evolving over time". ${ }^{28}$ In practice, the jurisprudence of the International Court of Justice (hereinafter ICJ) has adopted general denominations that include both subsequent agreement and subsequent practice. ${ }^{29}$

22 Yearbook of the International Law Commission, 1966, vol. II, UN Doc A/CN.4/L.117 and Add. 1, p. 221 (hereinafter Yearbook 1966). Commentaries to the VCLT.

23 Yearbook of the International Law Commission, 2013, UN Doc. A/68/102013. A.

24 See Introductory Report 2010, supra note 4, p. 8.

25 Yearbook of the International Law Commission, 2013, UN Doc. A/68/102013. A.

Chapter IV. Subsequent agreements and subsequent practice in relation to the interpretation of treaties. Comment 9 to conclusion 2, p. 23.

26 Yearbook of the International Law Commission, 2013, UN Doc. A/68/102013. A. Chapter IV. Subsequent agreements and subsequent practice in relation to the interpretation of treaties. Conclusion 2.

27 Second Report on subsequent agreements and subsequent practice in relation to the interpretation of treaties by Nolte, G. 26 March 2014.A/CN.4/671, p. 11.

28 Yearbook of the International Law Commission, 2013, UN Doc. A/68/102013. A. Chapter IV. Subsequent agreements and subsequent practice in relation to the interpretation of treaties. Conclusion 2.

29 In the Case concerning the Territorial Dispute (Libyan Arab Jamahiriya/Chad), ICJ Reports 


\subsection{Evolutive interpretation}

This criterion deals with the context and norms applicable as means of interpretation of a treaty after the passage of time, appealing to the current intentions of the States or the finding on the text of the agreement of terms that, by definition, are of evolutionary nature..$^{30}$ This approach acknowledges that treaties are intrinsically "porous to their legal environment. The normative character of a practice may therefore either be anchored in a conventional regime or derive from the international legal order" ${ }^{31}$ The intertemporality of treaties ${ }^{32}$ seeks to provide an answer as to whether a treaty should be interpreted in light of the factual and legal circumstances present at time when it was concluded (contemporaneous interpretation), or the circumstances prevailing at the time of application. ${ }^{33}$

1994, the Court uses the term "subsequent attitudes". In the Case concerning Maritime Delimitation and Territorial Questions between Qatar and Babrain (Qatar v. Bahrain) 1995, it uses "subsequent conduct". In the Case concerning the Gabcilkovo-Nagymaros Project (Hungary/Slovakia) 1997, the Court applies "subsequent positions." In the Case concerning the Sovereignty over Pulau Ligitan and Pulau Sipadan (Indonesia/Malaysia) 2002, the Court left the question open. In the Case concerning maritime dispute (Peru v. Chile), to determine the eventual agreement of the Parties upon a maritime boundary, the Court referred to "the practice of the Parties subsequent to the 1952 Santiago Declaration". 2014, ICJ Reports 2014, para. 103. Also see: Kasikili/Sedudu Island (Bostwana v. Namibia), 1999, ICJ Reports 1999. Certain Activities Carried out by Nicaragua in the Border Area (Costa Rica v. Nicaragua), 2015, ICJ Reports 2015, para. 61.

30 Advisory Opinion on the Legal Consequences for States of the continued Presence of South Africa in Namibia, ICJ Reports, 191, paras. 53, 54.

See also Bollecker, B., "L'Avis Consultatif du 21 Juin 1971 dans l'affaire de la Namibie (Sud-Ouest Africain)", Annuaire Français de Droit International 1971, 17, pp. 288-194.

Letsas, G., "The Truth in Autonomous concepts: How to Interpret the ECHR", EJIL, 2004, 2, pp. 279-305.

31 Boisson de Chazournes, L., Subsequent Practice, Practices and "Family-Resemblance": Towards embedding Subsequent Practice in its Operative Milieu - A Multi-Actor Perspective, IRPA Working Paper, GAL Series No. 1/2013, p. 7.

32 "[A] juridical fact must be appreciated in the light of the law contemporary with it, and not the law in force at the time when a dispute in regard to it arises or falls to be settled". Island of Palmas Case (Netherlands, United States) 2 R. Int'l Arb. Awards 831, 845.

33 Elias, T. O., The Doctrine of Intertemporal Law, 74 Am. J. Int'l L. 285 (1980), 258307.

ACDI, Bogotá, ISSN: 2027-1131/ISSNe: 2145-4493, Vol. 10, pp. 295-331, 2017 
In 1964, Article 56 of the travauxpréparatoires of current VCLT Article 31(3)(c) read: "In the light of the general rules of international law in force at the time of its conclusion". "When this Article was introduced to the ILC, some considered that it had not dealt specifically with the effect of an evolution of the law on the interpretation of legal terms in a treaty, and was therefore inadequate. ${ }^{35}$ The text only partially covered the question of intertemporal law, and the ILC concluded that the temporal element should be removed and the reference to international law revised, so as to make it read "any relevant rules of international law applicable in the relations between the parties". 36

Evolutive interpretation allows for new meanings to be applied to concepts in the text of a treaty and for the interpretation of terms in the scope and context of modern conditions. However, it does not entail absolute liberality for the interpreter to introduce new conceptual elements to the agreement, there by assuming a treaty-making role, which remains the purview of States and Organizations as international legal actors. ${ }^{37}$ In some scenarios, this approach provides for a wider spectrum of interpretative alternatives, even when it cannot introduce elements that were not initially incorporated in the wording of the treaty; it is not restricted to the practice of the Parties and can consider the effects of subsequent legal and factual developments concerning the matter interpreted. ${ }^{38}$

In the Inter-American Human Rights System, the evolutive interpretation of the American Convention on Human Rights (ACHR) has allowed the introduction of additional guarantees for the protection of rights, for example by interpreting the rights originally contained in a text in the con-

\footnotetext{
34 Yearbook 1966, supra note, p. 88.

35 Ibid.

36 Ibid.

37 ECHR, Felbrudge v. Netherlands, Judgment 23 April 1986, Case No. 8/1984/80/127, Joint dissenting opinion at paras. 23-24. See also Gardiner, R., Treaty Interpretation, Oxford University Press, Oxford, 2008, pp. 243-244.
}

38 Case concerning the Gabcikovo-Nagymaros Project (Hungary/Slovakia), Judgment of 25 September 1997, ICJ Reports 1997, para. 112. "By inserting these evolving provisions in the Treaty, the parties recognized the potential necessity to adapt the Project. Consequently, the Treaty is not static, and is open to adapt to emerging norms of international law. By means of Articles 15 and 19, new environmental norms can be incorporated in the Joint Contractual Plan".

Fragmentation conclusions, supra note 7, paras. 16-19. 
text of new legal developments as described in the Corpus iuris, ${ }^{39}$ which will be further explained below in a discussion on Inter-American Case Law.

\subsection{Criteria for the application of an evolutive interpretation of treaty provisions}

The ILC has concluded that evolutive interpretation results from the application of the means established in articles 31 and 32 of the VCLT. By incorporating criteria such as the nature of a term interpreted on a case-by-case basis, the evolutive interpretation of a term over time must result from the ordinary process of treaty interpretation. ${ }^{40}$ Furthermore, the applicability of such an interpretation should not be left entirely to the interpreter, but should be based upon the elements of the treaty, in particular its provisions, the intention of the parties, and its object and purpose. We have identified criteria for law-makers and legal interpreters to identify if the hermeneutic path to follow is to be evolutionary, such as the presence of a) evolutive terms in the treaty; b) an intertemporal law clause; and c) the intention of the parties. ${ }^{41}$

\subsubsection{Intrinsically evolutive terms in the treaty}

Case law has recognized certain provisions that make a treaty suitable for evolutive interpretation: context-dependent terms such as those used in the Namibia Opinion by the ICJ, ${ }^{42}$ and terms of generic character, as in the Aegean Sea Case. ${ }^{43}$ Meanwhile, the ILC's Conclusions on Fragmentation of International Law established the circumstances under which a treaty provision may be interpreted in light of international law subsequent to

\footnotetext{
39 Cfr. Sheeran, S., "The Relationship of international human rights law and general international law: hermeneutic constraint, or pushing the boundaries?", in Sheeran, S. \& Rodley, N., Routledge Handbook of International Human Rights Law, 2013, p. 102.

40 Yearbook of the International Law Commission, 2013, UN Doc. A/68/102013. Chapter IV. Subsequent agreements and subsequent practice in relation to the interpretation of treaties. Conclusion 3, commentary 8.

41 Also see Helmersen, S. "Evolutive Treaty Interpretation: Legality, Semantics and Distinctions", EJLS, 2013, 6, (I).

42 Legal Consequences for States of the Continued Presence of South Africa in Namibia (South West Africa) notwithstanding Security Council Resolution 276 (1970), ICJ Reports 1971, paras. 51-53.

43 Aegean Sea Continental Shelf(Greece v. Turkey), ICJ Reports 1978, para. 77.
} 
the treaty: (a) the concept is one that implies taking subsequent technical, economic, or legal developments into account; ${ }^{44}$ (b) the concept sets up an obligation for further progressive development for the parties; ${ }^{45}$ or (c) the concept has a very general nature or is expressed in such general terms that it must take changing circumstances into account. ${ }^{46}$ Furthermore, the nature of the term interpreted is the main criterion in the conclusions adopted by the ILC in $2013 .{ }^{47}$

\subsubsection{Intertemporal law clause}

Ideally, the parties can include a clause in the text of the treaty concerning the interpretative criteria or rules to follow when applying the instrument. The ILC Study Group on Fragmentation indicated "it seems pointless to try to set any general and abstract preference between the past and the present" ${ }^{48}$ Furthermore, this might be a result of the subsequent agreement

44 In the Case concerning the Gabčikovo-Nagymaros Project (Hungary v. Slovakia), Judgment of 25 September 1997, ICJ Reports 1997, para. 112. When analyzing the possibility of incorporating new international rules on environmental law into the treaty, the Court considered that it was feasible to do so due to the generality of some of the provisions in the treaty, stating that "by inserting these evolving provisions in the Treaty, the parties recognized the potential necessity to adapt the Project. Consequently, the Treaty is not static, and is open to adapt to emerging norms of international law".

45 On the debate over the progressive development of international law see Sinclair, I., The Vienna Convention on the Law of Treaties, supra 12, p. 18. Costa Rica v. Nicaragua Case, supra note 54 , para. 64. "[T] here are situations in which the parties' intent upon conclusion of the treaty was, or may be presumed to have been, to give the terms used —or some of them- a meaning or content capable of evolving, not one fixed once and for all, so as to make allowance for, among other things, developments in international law. In such instances it is indeed in order to respect the parties' common intention at the time the treaty was concluded, not to depart from it, that account should be taken of the meaning acquired by the terms in question upon each occasion on which the treaty is to be applied".

46 ICJ Namibia Opinion, supra note 42, para. 53. The ICJ held that "an international instrument has to be interpreted and applied within the framework of the entire legal system prevailing at the time of interpretation".

47 Yearbook of the International Law Commission, 2013, UN Doc. A/68/102013. A. Chapter IV. Subsequent agreements and subsequent practice in relation to the interpretation of treaties. Conclusion 3, comment 6.

48 Watts, A., Pronto, A. \& Wood, M., The International Law Commission 1999-2009, volume IV: Treaties, Final Draft Articles, and Other Materials, Oxford University Press, 2010, p. 803 , para. 478 . 
of the parties during the application of the treaty, or decisions adopted within the framework of a Conference of States Parties. ${ }^{49}$

Evidence of such agreement could be the case between Burkina Faso and Niger, where the parties provided specific indications of the applicable law, including "the principle of intangibility of boundaries inherited from colonization and the Agreement of 28 March 1987". 50 The ICJ applied the arreté over the village of Bangaré based on the "subsequent documents to establish that, during the relevant colonial period and until the critical date of independence, Bangaré had been administered by the authorities of the Colony of Niger". ${ }^{51}$ In 2014, the ILC concluded that, in essence, this criterion implied an acknowledgement of the agreement and common acceptance of the clause restricting the interpretation of the instrument. ${ }^{52}$

\subsubsection{Intention of the parties}

Considerations regarding the intention of the parties are imperative in the context of implementing an evolutive approach. As explained by Jiménez de Aréchaga at the ILC in 1964, the parties either intended to incorporate a concept that would remain unchanged into the treaty, or, "if they had no such intention, the legal concepts might be subject to change and would then have to be interpreted not only in the context of the instrument, but also within the framework of the entire legal order to which they belong". However, the intention of the parties shall not be limited by "crystallizing every concept as it had been at the time when the treaty was drawn up". ${ }^{53}$

In the Case of Costa Ricav. Nicaragua, the ICJ considered that since the parties used generic terms in the text of the treaty, they were consenting - especially if the treaty had been in force for a long time - to subject

\footnotetext{
49 See Yearbook of the International Law Commission, 2014, UN Doc. A/69/10. Draft Conclusion 10, p. 205.

50 ICJ. Special Agreement seizing the International Court of Justice of the boundary dispute between Burkina Faso and the Republic of Niger. Jointly communicated to the Court on 20 July 2010. ICJ Burkina Faso Niger, para. 64.

51 Idem., para. 95.

52 See Yearbook of the International Law Commission, 2014, UN Doc. A/69/10, p. 200. Comment 8 to draft Conclusion 9.

53 Yearbook of the International Law Commission, 1964, vol. I, UN Doc A/SER.A/1964, p. 34, para. 10 (hereinafter Yearbook 1964).
} 
those provisions of the treaty to the evolution of the terms over time. ${ }^{54}$ The ILC has additionally indicated that an understanding of the intention of the parties can be inferred from the inactivity of one of the parties over the conduct of the other (in a mode of acquiescence)..$^{55}$

Within the application of the evolutive interpretation as described in the VCLT, the use of travaux préparatoires and the circumstances under which the treaty was concluded, can often be required, in addition to the final wording of the text, as means to identify the intention of the parties and the evolution of the discussion prior to the conclusion of the treaty. ${ }^{56}$

Once the previous criteria have been identified for the application of evolutive interpretation, a question arises concerning the sources applicable to update the treaty's provisions to the time of their application. Two scenarios may trigger the application of an evolutionary perspective on a treaty: the emergence of a factual circumstance, and a legal change in time, in which case a resorting to the principle of "systematic integration" in concordance with Article 31 (3) (c) will be helpful. We will focus exclusively on the latter, highlighting that the change in the political context may become State conduct if consistent and repeated over time, acquiring legal value as described above.

\subsection{Defragmentation: Systematic integration as the key for evolutive interpretation}

The principle of "systematic integration" is considered to have the "status of a constitutional norm within the international legal system" 57 serving

54 Dispute regarding Navigational and Related Rights (Costa Rica v. Nicaragua), Judgment of 13 July 2009, ICJ Reports 2009, para. 66. "[W] here the parties have used generic terms in a treaty, the parties necessarily having been aware that the meaning of the terms was likely to evolve over time, and where the treaty has been entered into for a very long period or is 'of continuing duration', the parties must be presumed, as a general rule, to have intended those terms to have an evolving meaning".

55 Commentaries 14 and 15 to Draft Conclusion 9. ILC Yearbook 2013.

56 Villiger, M., “The Rules on Interpretation: Misgivings, Misunderstandings, Miscarriage? The 'Crucible' Intended by the International Law Commission”, in Canizzaro, E., The Law of Treaties Beyond the Vienna Convention, Oxford University Press, 2011, p.113.

Also see Aust, A., Modern Treaty Law and Practice, Oxford University Press, 2013, p. 217.

57 McLachlan, C., "The principle of Systematic Integration and Article 31 (3) (c) of the Vienna Convention”, International and Comparative Law Quarterly, vol. 54, April 2005, p. 280. ICLQ vol. 54, April 2005, pp. 279-320. 
by analogy as a master-key to a building. The use of individual keys will suffice to open the doors to particular rooms. In exceptional circumstances, it is necessary to use a master-key to access all of the rooms. ${ }^{58}$ Similarly, the framework established by the treaty may open some particular doors, but sometimes external sources are needed. A master-key called "systematic integration" found in the Article 31 (3) (c) incorporates "any relevant rules of international law applicable in relations between the parties" into the interpretative parameters to bring treaties or treaties provisions up to date.

Within such interaction, the ILC Conclusions on Fragmentation have recognized that "whatever their subject matter, treaties are a creation of the international legal system and their operation is predicated upon that fact".${ }^{59}$ Therefore, the relation between norms of clarification, application, update, or modification must be identified in accordance with VCLT rules on the interpretation of treaties. ${ }^{60}$

The nature of the treaty will provide the interpreter the elements to address the questions presented by the application of the treaty and in some scenarios, these elements will be found within the treaty framework itself. Article 31 (3) (c) "deals with the case where material sources external to the treaty are relevant in its interpretation. These may include other treaties, customary rules, or general principles of law". ${ }^{61}$

Hence, the use of a broad provision as "systematic integration" may pose the danger that the interpreter can incorporate elements into the treaty that the member States did not give their consent to incorporate or were even opposed to. In the Oil Platform Case, a landmark for the application of Article 31 (3) (c) as a framework of interpretation, the ICJ considered that this article "was thus used to introduce the entirety the law of jus ad bellum, even though, in the jurisdictional phase of the case, such Court stated that its competence was limited to considering Article

\footnotetext{
58 Ibid., pp. 280-281.

59 Fragmentation conclusions, supra note 7, para. 17.

60 International Law Commission, Fifty-eighth Session, Fragmentation of International Law: Difficulties Arising from The Diversification and Expansion of International Law, Report of the Study Group of the International Law Commission, Finalized by Martti Koskenniemi, Official Records of the General Assembly, Sixty-first Session (2006), A/61/10, para. 251 (hereinafter Fragmentation Conclusions).
}

61 Ibid., para. 18. 
X(1) of the Treaty of Amity-freedom of commerce". ${ }^{62}$ Renowned scholars have remarked that in such scenarios, "the provision brings with it as many problems as it resolves". ${ }^{63}$

\subsection{Evolutive Interpretation v. Subsequent Conduct?}

Generally, two outcomes may be extracted as the result of interpretation of treaties over time: i) the subsequent conduct of the parties, either by a tacit agreement evidencing a common understanding of the content of a provision, or an express one materialized in a legal instrument, gives rise to a particular way in which the instrument should be interpreted and applied. On the other hand, ii) when there is a change in the context, even without the intervention of the parties, such a change necessarily leads to a modification in the practical application of the provision to cover the appearance of factual scenarios that were unforeseen during the treatymaking process.

In practice, such different means of interpretations are not applied as independent perspectives, but rather as complementary tools. The Gabcikovo-Nagymaros Project case (Hungary/Slovakia) exemplifies treaty interpretation in light of subsequent acts, developments, and events that affect its existence, content or meaning. The ICJ held that newly developed norms of environmental law are relevant for the implementation of the Treaty and that the Parties could, by agreement, incorporate them through the application of several of its articles. ${ }^{64}$

The Costa Rica v. Nicaragua case concerning navigational rights over the San Juan River illustrates the relationship between subsequent conduct and evolutive interpretation. The Court faced the intertemporal question, having to choose whether to follow Nicaragua's request to apply the notion of comercio as it existed at the time the treaty was concluded, or as understood today by the parties. The ICJ determined that even when the terms of a treaty must be interpreted based on the parties' common intention contemporaneous with the conclusion of the treaty, such an approach does not preclude the possibility of considering the changed meaning of

\footnotetext{
62 Higgins, R., "A Babel of judicial voices? Ruminations from the bench", International and Comparative Law Quarterly, 2006, 55, pp. 802-803. ICLQ vol. 55, October 2006.

63 Ibid., pp. 803-804.

64 Gabcikovo-Nagymaros Project (Hungary/Slovakia), supra 38.
} 
the term at the time of interpretation for the purpose of its application. The Court concluded:

The subsequent practice of the parties, within the meaning of Article 31 (3) (b) of the Vienna Convention, can result in a departure from the original intent on the basis of a tacit agreement between the parties. $[\ldots]$ it is indeed in order to respect the parties' common intention at the time the treaty was concluded, not to depart from it, that account should be taken of the meaning acquired by the terms in question upon each occasion on which the treaty is to be applied. ${ }^{65}$

Judge Skotnikov challenged the real intention of the parties to apply a notion of commerce different from the one existing at the time the treaty was concluded, indicating that such approach "counter [ed] the principle that limitations on sovereignty are not to be presumed". ${ }^{66} \mathrm{He}$ further considered that "the Court should have examined the practice of the Parties subsequent to the conclusion of the Treaty", ${ }^{67}$ concluding that "the subsequent practice in the application of the Treaty suggests that the Parties have established an agreement regarding its interpretation: Costa Rica has a right under the 1858 Treaty to transport tourists". ${ }^{68}$

These common results let us conclude that the idea of interpretation discussed by the members of the ILC in 1966 is in force today. "[T] he application of the means of interpretation in the article [today's Article 31 (3)] would be a single combined operation. All the various elements, as they were presenting any given case, would be thrown into the crucible, and their interaction would give the legally relevant interpretation". ${ }^{69}$ The Costa Rica v. Nicaragua decision evidences how subsequent practice can complement the evolutive interpretation of the treaty, arriving at a more accurate and safer understanding of the parties' intentions.

The evolutionary interpretations or the systemic approach to treaties do not necessarily reach different results, but rather provide tools to address the same issue with different approaches, often providing the

\footnotetext{
65 Costa Rica v. Nicaragua, supra note 41, paras. 63-70.

66 Ibid., Costa Rica v. Nicaragua Case, Judge Skotnikov Dissenting Opinion, para. 6.

67 Ibid., para. 8.

68 Ibid., para. 10.

69 Yearbook 1966, supra note 23, p. 219, para. 8.
} 
same result in a complex interpretative operation. A careful and thoughtful interpretation under the principles of pacta sunt servanda, "systematic interpretation", ${ }^{70}$ and the notion that "treaties are not just dry parchments" but dynamic legal instruments, constitute the cornerstone for the "evolutive interpretation" of the treaty as an alternative for responding to new needs from international society and the emergence of new scenarios for treaty application. ${ }^{72}$

\section{Treaties over time in the jurisprudence of the Inter- American Court of Human Rights}

The ILC report on Fragmentation defines self-contained regimes ${ }^{73}$ as interrelated wholes of primary and secondary rules that cover some particular problem differently from general international law. ${ }^{74}$ Human rights treaties regulate the relations between states and individuals, "unlike treaties of the 'classical kind' since they go beyond reciprocal obligations". ${ }^{75}$ They are often identified as special in the sense that the rules of general international law are assumed to be modified or even excluded. "Protection takes the form of such arrangements for monitoring or ensuring respect for human rights as are provided for in the conventions themselves", ${ }^{76}$ providing principles for interpretation, which might differ from general law in analogous situations. ${ }^{77}$

\footnotetext{
70 Fragmentation conclusions, supra note 7, paras. 16-19.

71 ORGA 2008, supra note 1, p. 365.

72 Ibid., p. 366.

73 On the origin of self-contained regimes, see Case concerning United States Diplomatic and Consular Staff in Tehran (United States of America v. Iran), 24 May 1980, p. 38. S. S. Wimbledon, PCIJ, Serie A No. 1, at 23.

74 Cfr. Koskenniemi, M., para 128. Also see: Simma, B. \& Puylkowski, D., “Of Planets and the Universe: Self-contained Regimes in International Law”, 17 EJIL 2006 No. 3.

75 Ireland vs. UK, ECTHR, Serie A vol. 25, para. 239.

Also see I/A Court of H. R., The Effect of Reservations on the Entry into Force of the American Convention on Human Rights, Advisory Opinion OC-2/82, Serie A No. 2, 1982, at paras. 29-31.

76 Military and Paramilitary Activities in and against Nicaragua (Nicaragua v. United States of America), Merits, ICJ Reports 1986, p. 134.

77 Koskenniemi report, para. 129.
} 
Through an analysis of the jurisprudence of the Inter-American Court of Human Rights (IACTHR), in this chapter we will evidence the use of interpretive means such as "subsequent conduct", "evolutive interpretation", and systemic approaches, which are general rules applied but not limited to the specific context of human rights provisions. This chapter seeks to demonstrate that even when the IACTHR has applied particular interpretative theories, the rules for interpretation of human rights treaties are essentially the same as for any other treaty.

\subsection{Human Rights Law: Special regimes and the need for unification}

The international legal system "consists of erratic parts and elements which are differently structured so that one can hardly speak of a homogeneous nature of international law. This system is full of universal, regional or even bilateral systems, subsystems and sub-subsystems of different levels of legal integration". ${ }^{78}$ However, this does not imply that a special interpretation model needs to be developed for each of these systems, subsystems, or sub-subsystems. The peril of fragmentation arises, as indicated in 1988 by Ian Brownlie, "from the tendency to separate the law into compartments. Various programs or principles are pursued without any attempt at coordination. After all, enthusiasts tend to be single-minded. Yet there may be serious conflicts and tensions between the various programs or principles concerned". ${ }^{79}$ The response to fragmentation phenomena will be an interpretation procedure based on the principles of harmonization and systematic integration. ${ }^{80}$

The ILC indicated in its Report on Fragmentation that self-contained regimes, such as human rights regimes, operate in a way similar to lex specialis, prevailing over general international law. However, general international law plays two roles regarding self-contained regimes: (a) as gap-filling, due to the larger scope of general international law it is able to provide regulations that self-contained regimes have not specified. ${ }^{81}$

\footnotetext{
78 McLachlan, C., ver nota 57 supra note, p. 238.

79 Brownlie, I., "The Rights of Peoples in Modem International Law", in Crawford, J. (eds.), The Rights of Peoples, Clarendon Press, Oxford, 1988, pp. 1-16.

80 Fragmentation conclusions, supra note 7.

81 Fragmentation conclusions, supra note 7, para. 11, para. 15. Bankovic v. Belgium and others,
} 
And (b) as a tool upon the failure of special regimes, when the objectives are not met or there is non-compliance or withdrawal. In the last scenario, it still "would have to be assessed above all by an interpretation of its constitutional instruments. In the event of failure of the lex specialis, the relevant general law becomes applicable". ${ }^{82}$

Concerning treaty interpretation, the ILC reports on Fragmentation and Subsequent Agreements and Practice have approached human rights treaty interpretation from a European perspective, indicating that principles of dynamic or teleological interpretation focused in the object and purpose of the instruments are "more deeply embedded in human rights law than in general international law". ${ }^{83}$

\subsection{The Inter-American Human Rights Court Interpretative Clause}

The IACTHR is a conventional organ established by the American Convention on Human Rights. Even though the ACHR does not provide a special interpretation regime different from the VLCT customary provisions, it does establish a guiding principle derived from the object and purpose of the treaty as a starting point for the Court. ${ }^{84}$

Article 29 of the American Convention indicates that there shall be no interpretation of the Convention that may allow the suppression or excessive restriction of rights ${ }^{85}$ or freedoms or that may preclude guarantees

Decision of 12 December 2001, Admissibility, ECHR 2001-XII, p. 351 Korea - Measures Affecting Government Procurement (19 January 2000) WT/DS163/R, para. 7.96.

82 Ibid., para. 16.

83 Koskenniemi, M., para. 130. For the role of "dynamic" or "teleological" interpretation in human rights law, see Wachsmann, P., "Les methodes de l'intérpretation des conventions à la protection des droits de l'homme", in SFDI, La protection des droits de l'homme et l'évolution du droit international, Coll. 1998, Pedone, Paris, 1998, pp. 188-193.

84 See also Caflisch, L. \& Cancado Trindade, A., "Les conventions americaine et européenne des droits de l'homme et le droit international général”, RGDIP, 2004, 108, pp. 11-22.

85 Salvioli, S., "Un análisis desde el principio pro persona sobre el valor jurídico de las decisiones de la Comisión Interamericana de Derechos Humanos", in En defensa de la Constitución: libro homenaje a Germán Bidart Campos, Ed. Ediar, Buenos Aires, Argentina, 2003, pp. 143-155. 
that are inherent in the human personality or derived from representative democracy as a form of government. ${ }^{86}$

Having protection of the individual as the main object and purpose of the provisions, the propersona principle becomes a guiding light for the choice of interpretative rules applicable on a case by case analysis. Accordingly, the Court has established some common rules of interpretation via case law that are a constant in the Inter-American System: i) "human rights treaties are live instruments whose interpretation must go hand in hand with evolving times and current living conditions", 87 ii) the process of interpretation must be "consistent with the general rules of interpretation set forth in Article 29 of the American Convention, as well those set forth in the Vienna Convention on Treaty Law [...]", 88 and finally, "when interpreting the Convention it is always necessary to choose the alternative that is most favorable to protection of the rights enshrined in said treaty, based on the principle of the rule most favorable to the human being". ${ }^{89}$

86 Also see Pinto, M., "El principio pro homine. Criterios de hermenéutica y pautas para la regulación de los derechos humanos", in La aplicación de los tratados de derechos humanos por los tribunales locales, Centro de Estudios Legales y Sociales (CELS), Editorial del Puerto, Buenos Aires, 1997, p. 163. Cfr. Ferrer Mac-Gregor, E., "Interpretación conforme y control difuso de convencionalidad. El nuevo paradigma para el juez mexicano", in Carbonell, M. \& Salazar, P. (coords.), La reforma constitucional de derechos humanos: un nuevo paradigma, Instituto de Investigaciones Jurídicas - UNAM, México, 2011, p. 366.

87 See Tyrer $v$. The United Kingdom, ECtHR, 1978, Serie A No. 26, para. 31.

88 See The Right to Information on Consular Assistance in the Framework of the Guarantees of the Due Process of Law, Advisory Opinion OC-16/99 of October 1, 1999, Serie A No. 16, para. 114. Also see among the adjudicatory cases Case of the Indigenous Community Yakye Axa, supra note 12; I/A Court H. R., Case of the Gómez Paquiyauri Brothers v. Peru, Merits, Reparations and Costs, Judgment of July 8, 2004, Serie C No. 110, paras. 165, 146; I/A Court H. R., Case of Juan Humberto Sánchez, Interpretation of the Judgment on Preliminary Objections, Merits and Reparations (Art. 67 American Convention on Human Rights), Judgment of November 26, 2003, Serie C No. 102, para. 56; Case of the Mayagna (Sumo) Awas Tingni Community, Judgment of August 31, 2001, Serie C No. 79, paras. 146-148; and I/A Court H. R., Case of Barrios Altos v. Peru, Merits, Judgment March 14, 2001, Serie C No. 75, paras. 41-44.

89 See I/A Court H. R., Case of Ricardo Canese v. Paraguay, Merits, Reparations and Costs, Judgment of August 31, 2004, Serie C No. 111, para. 181; I/A Court H. R., Case of Herrera Ulloa v. Costa Rica, Preliminary Objections, Merits, Reparations and Costs, Judgment of July 2, 2004, Serie C No. 107, para. 184; and I/A Court H. R., Case of Baena Ricardo et al. v. Panama, Merits, Reparations and Costs, Judgment of February 2, 2001, Serie C No. 72. 


\subsection{Interpretative approach of the IACTHR to current issues of evolutive interpretation of the ACHR}

\subsubsection{Human Rights and International Humanitarian Law: Another self - contained regime?}

In some cases, the IACTHR had to adjudicate regarding possible violations of human rights within the context of armed conflict where international humanitarian law is applicable. ${ }^{90}$ Even though the Court lacks jurisdiction to declare responsibility for the violation of obligations contained in instruments other than the American Convention and the Pact of San José, this lack of adjudicative mandate did not preclude the application of jus in bello via systematic interpretation.

In the Case of the Mapiripan Massacre v. Colombia, ${ }^{91}$ the Court indicated that "said provisions are useful to interpret the Convention" in the process of establishing the responsibility of the State and other aspects of the violations alleged in the instant case". It further reviewed that IHL rules were in force for Colombia at the time of the facts of the case, both as international treaty obligations ${ }^{93}$ and as domestic laws, part of the

90 See I/A Court H. R., Case of the Serrano Cruz Sisters v. El Salvador, Preliminary Objections, Judgment of November 23, 2004, Serie C No. 118, para. 108; and I/A Court H. R., Case of Las Palmeras v. Colombia, Preliminary Objections, Judgment of February 4, 2000, Serie C No. 67, para. 33.

91 I/A Court H. R., Case of the Mapiripán Massacre v. Colombia, Merits, Reparations and Costs, Judgment of September 15, 2005, Serie C No. 134.

Also see Burgorgue, L., The Inter-American Court of Human Rights: Case Law and a Commentary, p. 54: "Colombia established a distinction between the "interpretation of" and "the application of". The Court may interpret the Geneva Conventions and other international treaties, but it may only apply the American Convention.

92 See Case of the Serrano Cruz Sisters, Preliminary Objections, supra note, para. 119; Case of Las Palmeras, Preliminary Objections, supra note, paras. 32-34; and I/A Court H. R., Case of Bámaca Velásquez. v. Guatemala, Merits, Judgment of November 25, 2000, Serie C No. 70, paras. 208-209.

93 Protocol II was ratified by Colombia on August 14, 1995 and entered into force on February 14, 1996. Protocol Additional to the Geneva Conventions (Protocol II), 8 June 1977, 1125 UNTS 609. 
"Constitutional block", ${ }^{94}$ making compliance mandatory for both State and non-State actors involved in the conflict. ${ }^{95}$

In the 2005 Mapiripan case, the Court applied the pro personae principle, considering the national and international behavior of Colombia, to incorporate IHL into the interpretation of ACHR clauses and attribute responsibility to the State. With this decision, the Court may have departed from the original intention of the parties, due to the lack of jurisdiction ratione materiae to declare responsibility on the grounds of IHL. $^{96}$

However, when addressing another case that involved human rights violations in an armed conflict in 2014, the Parties in the case of Cruz Sánchez v. Peru and the Inter-American Commission acknowledged such a systematic approach, coinciding that "the Court shall interpret the norms of the American Convention in the present case in light of the pertinent dispositions in international humanitarian law, considering that the facts occurred in the context of an armed conflict of a non-international character". ${ }^{97}$

In this case, the Court considered it useful and appropriate, given the specificity of the matter, to take into consideration Common Article 3 of the Geneva Conventions and customary international humanitarian law. Moreover, the Court considered it to be "unquestionable that the dispositions of the American Convention related to the right to life keep

94 Law 171 of December 16, 1994, adopting the "Protocol additional to the Geneva Conventions of August 12,1949, regarding protection of the victims of non-international armed conflicts (Protocol II)".

95 See judgment C-225/95 of May 18, 1995, issued by the Constitutional Court.

96 Cfr. "The Inter-American Court appears to treat all the processes that generate these norms as equally valid forms of 'evolution' capable of influencing the interpretation of states' obligations under the American Convention. This generous notion of 'evolution' bypasses the consensual aspect of human rights without necessarily ensuring that the resulting interpretation is justified in institutional terms". In Newman, G., "Import, Export, and Regional Consent in the Inter-American Court of Human Rights", EJIL, 2008, 19, (1), p. 114.

97 I/A Court H. R., Case of Cruz Sánchez v. Peru, Preliminary Exceptions, Merits, Reparations and Costs, Judgment of April 17, 2015, Serie C No. 292, para. 267. On the application of IHL and the American Convention also see I/A Court H. R., Case of Massacres of El Mozote v. El Salvador, Preliminary Exceptions, Merits, Reparations and Costs, Judgment of October 25, 2012, Serie C No. 292, para. 148. 
their full validity and applicability in situations of armed conflict". ${ }^{98}$ Accordingly, "international humanitarian law does not displace the applicability of Article 4 of the Convention, but it nourished the interpretation of the conventional clause that prohibits the arbitrary deprivation of life because the facts occurred in a contest of armed conflict and with occasion of the same".

Since the American Convention does not expressly define the scope of arbitrariness that qualifies a deprivation of life in the context of armed conflict, the Court has indicated that

\begin{abstract}
it is pertinent to resort to the corpus iuris of applicable international humanitarian law to determine the scope of State obligations concerning the respect and guarantee of the right to life in such situations. It becomes evident that the Court, via systematic interpretation, has pursued a harmonization of the protection of the rights and guarantees standard in both systems. The analysis of the possible violation of Article 4 of the American Convention shall consider among others the principle of distinction, the principle of proportionality and the principle of precaution. $^{99}$
\end{abstract}

\title{
3.3.2. Due Process and the Right to Information on Consular Assistance
}

In its Advisory Opinion OC-16/99, ${ }^{100}$ the IACTHR addressed the question presented by Mexico on whether the non-observance of the right to information violated the rights recognized in Article 14 of the ICCPR, Article 3 of the OAS Charter, and Article II of the American Declaration. Since the question presented involved the interpretation of treaties other than the American Convention, the Court used Article 31 of the VCLT as its interpretative framework. The "evolutive interpretation" was the mechanism applied to interpret the Convention, taking a systematic integration approach according to the rules set in the VCLT.

\footnotetext{
98 Cruz Sánchezv. Peru, 271.

99 Cruz Sánchezv. Peru, 273.

100 I/A Court H. R., The Right to Information on Consular Assistance. In the Framework of the Guarantees of the due Process of Law, Advisory Opinion OC-16/99 of October 1, 1999, Serie A No. 16.
} 
The analysis of the Court included the principle of good faith enshrined in article 31, and the ordinary meaning of the text, further indicating that "the effective protection of human rights constitutes the object and purpose of the of the American Convention, so when interpreting it the Court shall do so in the sense that the human rights protection regime has all its proper effects (effet utile)". ${ }^{101}$ The Court has further indicated that: "To protect the individual and see justice done, the historical development of the judicial process has introduced new procedural rights. An example of the evolutive nature of judicial process are the rights against self- incrimination and the right to have an attorney present when one speaks". ${ }^{102}$

Furthermore, the Court referred in this decision to the corpus juris of international human rights law, as "composed by a group of international instruments of various legal effects (treaties, conventions, resolutions, and declarations)". ${ }^{103}$ The Court considered the effectiveness of the instrument to develop the aptitude of international law to regulate relations between States and human beings. In several cases, this need has led the Court to "adopt the proper approach to consider this question in the context of the evolution of the fundamental rights of the human person in contemporary international law". ${ }^{104}$

The protection of due process has been the main right in which the effet utile $e^{105}$ has been considered a guiding principle for the interpretation of the convention in every particular case. The consideration of the passage of time for the purpose of applying the treaty has included issues such as the difference between human time and time for the purpose of

\footnotetext{
101 See ibid., para. 58.

102 Ibid., para. 117. See also Judge Cancado Trindade opinion in I/A Court H. R., Case of the Pueblo Bello Massacre v. Colombia, Merits, Reparations and Costs, Judgment of January 31, 2006, Serie C No. 140, paras. 33-34. And I/A Court H. R., Case of Claude-Reyes et al. v. Chile, Merits, Reparations and Costs, Judgment of September 19, 2006, Serie C No. 151. On the recognition of the evolutionary nature of due process and the need to use an "evolutive interpretation".

103 Advisory Opinion OC-16/99, supra note 79, para. 119.

104 Ibid., para. 115.

105 "Among several possible constructions, the principle of effective interpretation requires adopting the interpretation that best gives effect to the norm in question. Effectiveness includes the notion of enforceability". Simma, B. \& Puylkowski, D., supra, p. 508.
} 
access to justice ${ }^{106}$ and the delays in truth-seeking involving mass crimes which have challenged the effectiveness of the Convention itself by perpetuating impunity. ${ }^{107}$

\subsubsection{Indigenous Communities' Right to Property}

One of the scenarios in which the case law of the IACTHR has evidenced a challenge to the passage of time and the recognition of the obligations of States under the American Convention has been the interpretation of the right to property in the case of indigenous communities. Due to the particular understanding of property by ancestral communities in different States in Latin America, the application of such rights, recognized in Article 21 of the American Convention has been a representative scenario for the use of Corpus iuris as a mechanism to give effect to the protection of such communities and their ways of life.

In the Case of the Mayagna (Sumo) Awas Tingni Community v. Nicaragua the Court adopted an evolutionary interpretation pursuing the pro persona principle, in compliance with Article 29 (b) of the Convention, which prohibits the restrictive interpretation of rights. It required consideration of indigenous customary law, particularly regarding the possession of land as the only criterion for the determination of the right to property over territory, as illustrative sources of the evolutive interpretation process. ${ }^{108}$

Relying on the context in which the legal provision was to be applied, the IACTHR held in the Case of the Moiwana Community v. Suriname that the material possession of the indigenous communities and the link to ancestral property suffice as criteria for the legal recognition of the right in question. ${ }^{109}$ Furthermore, under a Systematic approach, the Court

106 See Dissenting Opinion, Judge Cancado. I/A Court H. R., Bulacio v. Argentina, Judgement of September 18, 2003, Serie C No. 100, para. 37.

107 I/A Court H. R., Massacre of El Mozote v. El Salvador, supra, paras. 51, 174.

108 Inter-American Convention of Human Rights, San José, Costa Rica, 22 November 19691144 UnTs 123. Also see I/A Court H. R., Case of the Mayagna (Sumo) Awas Tingni Community v. Nicaragua, Merits, Reparations and Costs, Judgment of August 31, 2001, Serie C No. 79 , paras. 142-153.

109 I/A Court H. R., Case of the Moiwana Community v. Suriname, Preliminary Objections, Merits, Reparations and Costs, Judgment of June 15, 2005, Serie C No. 124, paras. 130-131. 
considered in the Case of the Yakye Axa Indigenous Community v. Paraguay ${ }^{110}$ that other international law provisions including ILO Convention 169 compose the corpus iuris protecting indigenous communities, and are to be included in the considerations regarding the development of human rights law.

The application of corpus iuris of international law that protects, in particular, the rights of indigenous communities, has been incorporated under the pro persona principle to protect communities with a wider conception of the right to property. Simultaneously, the consideration of the context, referring to the customary uses of the community, has led to the systemic approach through the incorporation and recognition of traditions under the Scope of the American Convention, essentially using the following criteria: ${ }^{111}$

1) traditional possession of their lands by indigenous people has equivalent effects to those of a full state-granted property title; 2) traditional possession entitles indigenous people to demand official recognition and registration of property title; 3) the members of indigenous peoples who have unwillingly left their traditional lands, or lost possession thereof, maintain property rights thereto, even though they lack legal title, unless the lands have been lawfully transferred to third parties in good faith; and 4) the members of indigenous peoples who have unwillingly lost possession of their lands, when those lands have been lawfully transferred to innocent third parties, are entitled to restitution for those lands or to obtain other lands of equal size and quality. Consequently, possession is not a requisite condition for indigenous land restitution rights. ${ }^{112}$

\subsubsection{In Vitro Fertilization Case}

In addition, the interpretation of the Court has faced challenges concerning factual scenarios existing at the time of the drafting but not included

110 I/A Court H. R., Case of the Yakye Axa Indigenous Community v. Paraguay, Merits, Reparations and Costs, Judgment of June 17, 2005, Serie C No. 125, paras. 124-131.

111 I/A Court H. R., Case of the Sawhoyamaxa Indigenous Community v. Paraguay, Merits, Reparations and Costs, Judgment of March 29, 2006, Serie C No. 146, paras. 117-128.

112 I/A Court H. R., Case of the Saramaka Indigenous Community v. Suriname, Preliminary Exceptions, Merits, Reparations and Costs, Judgment of August 12, 2008, Serie C No. 185.

See also I/A Court H. R., Case of the Sarayaku Indigenous Community v. Ecuador, Merits, and Reparations, Judgment of June 27, 2012, Serie C No. 245. 
in the Convention, such as the scenarios addressed above, but also new de facto scenarios that were unforeseeable when the States consented to the application.

Unlike those affected by an ordinary inter-State treaty, individuals affected by the "application or non-application of a human rights treaty" are unable to clearly evidence a subsequent agreement between the Parties that has a negative effect on their enjoyment of human rights. The possibility of evidencing subsequent practice in Human Rights is frequently reduced to the eventual appearance of comparative law on the same issue within the jurisdiction of other State parties.

In 2012, the Court needed to interpret the scope of application of the right to life and determine the moment when such protection begins as part of its analysis of the prohibition of in vitro fertilization (IVF) in Costa Rica. The Court again took a systemic approach, comparing the scope of protection of other international human rights instruments. It addressed supplementary means of interpretation set out in Article 32 of the VCLT, including the travaux preparatoires, seeking an application of an intertemporal rule to determine the meaning that the Parties initially sought, considering that IVF did not exist when the Convention was concluded. The Court took note of its interest in human rights agreements as living instruments and the consistency of the evolutionary interpretation with the pro persona principle and the VCLT:

Upon an evolutionary interpretation, the Court has given special relevance to comparative law, by using national legislation or jurisprudence of national courts when analyzing specific disputes in contentious cases. The European Court has used comparative law as a mechanism to identify subsequent State practice, i. e. to specify the context of a particular treaty. In addition, the third paragraph of Article 31 of the Vienna Convention authorizes the interpretation of means such as agreements or practice or relevant rules of international law that States have expressed on the subject of the treaty, which is related to an evolutionary approach to treaty interpretation. ${ }^{113}$

113 See also I/A Court H. R., Case of Artavia Murillo and others (In Vitro Fertilization) V. Costa Rica, Preliminary exceptions, Merits, Reparations and Costs, Judgement of November 28, 2012, Serie C No. 257. 


\subsubsection{Advisory Opinion Concerning the Rights of Migrant Children}

In 2014, the Court determined the measures due by States for the protection of children, associated with their migratory condition, in accordance with the obligations contained in the American Convention. The IACTHR based its considerations on the VCLT general rules of "good faith, the natural meaning of the terms used in the treaty in question, the context, and the object and purpose", ${ }^{114}$ indicating that

53. [...] At this point it is essential to bear in mind the specificity of human rights treaties, which create a legal order in which States assume obligations towards all individuals within [their] jurisdiction and whose violations may be claimed by them and by the community of States Parties of the Convention through the action of the Commission and even before the Court, all of which have the effect that the interpretation of rules should also develop from a values-based model that seeks to protect American system, from the "best angle" for the protection of the person.

The practice of the IACTHR evidences the clear continuity of the approach taken by the drafters of the Convention concerning the lack of specific rules of interpretation in international human rights law. The case law of the Tribunal has been consistent in applying the general rules of treaty interpretation while incorporating elements of other instruments under a systemic approach to nourish the scope of the protection of the individuals.

\section{Conclusion: The Work of the Study Group regarding Human Rights ToT - Fragmentation or Unification-}

The analysis of Human Rights Law shows itself to be relevant for the study of treaties over time, and from its regime we can deduce that the two main techniques of interpretation, regarding "subsequent conduct" and "evolutive interpretation", far from contradicting each other, are mutually complementary. Recalling the analysis of the dispute that

114 I/A Court H. R., Rights of migrant children in the context of migration and/or in need of international protection, Advisory Opinion OC-21/14 of August 19, 2014, Serie A No. 21. 
produced Costa Rica v. Nicaragua, and paraphrasing the ILC preliminary work of 1964 for the Law of Treaties, interpreting a treaty is an art that uses different means of interpretation in a single combined operation.

The case law of the Inter-American Court of Human Rights demonstrates that the hypothesis suggested at the beginning of the jurisprudential analysis was correct. While supporting the conclusions on a general regime of interpretation, the case law studied challenges the original approach of the ILC concerning treaties over time, particularly the 2008 Report on the Fragmentation of International Law, which addresses Human Rights as a self-contained regime with specific rules of interpretation.

From the cases analyzed, concerning issues related to the influence of time in the application of human rights law, it is possible to determine the incidence of time in treaty interpretation at different moments. Some of the key moments for the purpose of interpretation vary from the travaux préparatoires, the underlying conceptions of the drafters, the adopted texts of some instruments concerning the same topics, and the very notion of human rights treaties as living instruments. ${ }^{115}$

This evidence reinforces the conclusions presented by the Study Group on Subsequent Agreement and Practice, which has omitted the creation of a different set of rules for the interpretation of human rights and has highlighted the use of national legislation as evidence of subsequent practice in the IACTHR. ${ }^{116}$ These conclusions have further stated that "the rights and obligations under human rights treaties must be correctly transformed, within the margin of appreciation, into the law and the international agreements of the respective State party". 117

The "evolutive interpretation" and "systemic interpretation" approaches embrace the object and purpose of human rights treaties that impose obligations on States to protect the rights of individuals. Subsequent practice must be analyzed within the scope of the threshold consented to by the international community and in accordance with principles of

115 Cfr. Pulp Mills on the River Uruguay (Argentina v Uruguay), Merits, April 20, 2010 ICJ Separate Opinion of Judge Antonio Cançado Trindade, paras. 116, 117.

116 Yearbook of the International Law Commission, 2014, UN Doc. A/69/10, para. 175.

I/A Court H. R., Hilaire, Constantine and Benjamin and others v. Trinidad and Tobago, Judgments, Merits, Reparations and Costs, Judgment, 21 June 2002, IACTHR, Serie C No. 94, para. 12.

117 Yearbook of the International Law Commission, 2014, UN Doc. A/69/10.p.193, para. 4. 
human rights such as the effet utile, propersona, and the corpus iuris approaches particular to human rights as recognized in the American Convention.

The principle of effet utile as the very purpose of effective protection of human rights recognized in the American Convention paves the way for the application of the evolutive approach, while the principle of pro persona for the systemic interpretation of the rights contained in the Convention and the subsequent developments in other systems or even domestic jurisdictions through the corpus juris. While the first has usually corresponded to interpretation based on the changed context in which rights are to be guaranteed, the second usually embodies the pursuit of harmony with the developments in other instruments for the protection of human rights providing a wider margin of protection for individuals.

In the words of Mme. Boisson de Chazourne, "Attempts at containment are thwarted by the emergence of similar trends under thematically different regimes. The latter trend rather supports the view that the species of practice tends to absorb and give legal shape to both pragmatic and value-oriented societal demands". ${ }^{118}$

The preliminary conclusions of the ILC study group on the rules of treaty interpretation regarding subsequent agreement and subsequent practice are complemented by the jurisprudence of the Inter-American Court, which evidences how, through interpretation, a self-contained regime can harmonize itself with general international law.

Human rights principles as a set of rules applicable to daily human conduct constantly face challenges due to the passage of time, including the emergence of unforeseen factual scenarios at the conclusion of a treaty, or when new guarantees arise in the context of rights that have already been recognized.

The case law analyzed has demonstrated that even when time poses a significant challenge for the application of human rights provisions, general rules of treaty interpretation derived from the VCLT provide the necessary tools to address the task. When interpreted under the lens of the object and purpose of this regime, which is no other than the protection of the individual, the general rules of interpretation provide the required answer, as indicated in the Report on Fragmentation, rather than functioning as gap-fillers or back up tools. Instead, creating a special regime for human rights will turn down the existing bridge between lex specialis and lex

118 Boisson de Chazournes, L., op. cit., p. 21. 
generalis, which at the end will have only negative consequences, weakening both regimes and challenging the effet utile of the provisions vis-à-vis the individuals that it seeks to protect.

\section{References}

\section{Conventions}

Inter-American Convention on Human Rights, San José, Costa Rica, 22 November 1969, 1144 UNTS 123.

Protocol Additional to the Geneva Convention (Protocol II), 8 June 1977, 1125 UNTS 609.

Vienna Convention on the Law of Treaties, 1155 unTs 331, 8 ILM 679.

\section{International documents}

Harvard Law School, Research in International IMW, part III. Law of Treaties, Introductory report presented by Georg Nolte to the Study Groups on Treaties Over Time, Jurisprudence of the International Court of Justice and arbitral tribunals of ad hoc jurisdiction relating the subsequent agreements and the subsequent practice.

International Law Commission, Fifty-eighth Session, Fragmentation of International Law: Difficulties Arising from the Diversification and Expansion of International Law, Report of the Study Group of the International Law Commission, Finalized by Martti Koskenniemi, Official Records of the United Nations General Assembly, Sixty-first Session, 2006, A/61/10.

Second report on subsequent agreements and subsequent practice in relation to the interpretation of treaties, by Georg Nolte, 26 March 2014.A/CN.4/671.

Special Agreement seizing the International Court of Justice of the boundary dispute between Burkina Faso and the Republic of Niger, Jointly notified to the Court on 20 July 2010.

Yearbook of the International Law Commission, 1964, vol. I, UN Doc A/ SER.A/1964.

Yearbook of the International Law Commission, 1966, vol. II, UN Doc A/ CN.4/L.117.

Yearbook of the International Law Commission, 2013, UN Doc. A/68/10. A. Chapter IV. Subsequent agreements and subsequent practice in relation to the interpretation of treaties. 


\section{International judgments}

Advisory Opinion on the Legal Consequences for States of the Continued Presence of South Africa in Namibia. ICJ Reports, 191.

Air Transport Arbitration Award (USA v. France), Award of 22 December 1963, UNRIAA, vol. XVI.

Beagle Channel Arbitration (Argentina v. Chile), 1977, ILR 52, 93.

Bankovic v. Belgium and others, Decision of 12 December 2001, Admissibility, ECHR 2001-XII, p. 351.

Case concerning Certain Activities Carried out by Nicaragua in the Border Area

(Costa Rica v. Nicaragua), 2015, ICJ Reports 2015.

Case concerning Kasikili/Sedudu Island (Bostwana v. Namibia), 1999, ICJ Reports 1999.

Case concerning Maritime Delimitation and Territorial Questions between Qatar and Babrain (Qatar v. Bahrain), ICJ Reports 1995.

Case concerning maritime dispute (Peru v. Chile), 2014, ICJ Reports 2014.

Case Concerning Military and Paramilitary Activities in and against Nicaragua (Nicaragua v. United States of America), Merits, ICJ Reports 1986, 134.

Case concerning the Dispute regarding Navigational and Related Rights (Costa Rica

v. Nicaragua), Judgment of 13 July 2009, ICJ Reports 2009.

Case concerning the Gabcikovo-Nagymaros Project (Hungary/Slovakia), Judgment of 25 September 1997, ICJ Reports 1997.

Case concerning the Pulp Mills on the River Uruguay (Argentina v Uruguay), Merits, April 20, 2010 ICJ.

Case concerning Sovereignty over Pulau Ligitan and Pulau Sipadan (Indonesia/ Malaysia), ICJ Reports 2002.

Case concerning the Temple of Prêab Vihéar (Cambodia v. Thailand), Judgment of 15 June 1962, ICJ Reports 1962.

Case concerning United States Diplomatic and Consular Staff in Tehran (United States of America v. Iran), 24 May 1980.

ECHR, Felbrudge v. Netherlands, Judgment 23 April 1986, Case 8/1984/80/127.

Ireland vs. UK, ECtHR, Serie A vol. 25.

I/A Court H. R., Case of Artavia Murillo and others (In Vitro Fertilization) v. Costa Rica, Preliminary exceptions, Merits, Reparations and Costs, Judgment of November 28, 2012, Serie C No. 257.

I/A Court H. R., Case of Barrios Altos v. Peru, Merits, Judgment March 14, 2001, Serie C No. 75, paras. 41-44. 
I/A Court H. R., Case of Baena Ricardo et al. v. Panama, Merits, Reparations and Costs, Judgment of February 2, 2001, Serie C No. 72.

I/A Court H. R., Case of Bámaca Velásquez v. Guatemala, Merits, Judgment of November 25, 2000, Serie C No. 70.

I/A Court H. R., Case of Cruz Sánchez v. Peru, Preliminary Exceptions, Merits, Reparations and Costs, Judgment of April 17, 2015, Serie C No. 292.

I/A Court H. R., Case of the Gómez Paquiyauri Brothers v. Peru, Merits, Reparations and Costs, Judgment of July 8, 2004, Series C No. 110.

I/A Court H. R., Case of Herrera Ulloa v. Costa Rica, Preliminary Objections, Merits, Reparations and Costs, Judgment of July 2, 2004, Serie C No. 107.

I/ A Court H. R., Case of Juan Humberto Sánchez, Interpretation of the Judgment on Preliminary Objections, Merits and Reparations, Judgment of November 26, 2003, Serie C. No. 102.

I/A Court H. R., Case of Las Palmeras v. Colombia, Preliminary Objections, Judgment of February 4, 2000, Serie C No. 67, para. 33.

I/A Court H. R., Case of Massacres of El Mozote v. El Salvador, Preliminary Exceptions, Merits, Reparations and Costs, Judgment of October 25, 2012, Serie C No. 292.

I/A Court H. R., Case of the Mayagna (Sumo) Awas Tingni Community, Judgment of August 31, 2001, Serie C No. 79.

I/A Court H. R., Case of Ricardo Canese v. Paraguay, Merits, Reparations and Costs, Judgment of August 31, 2004, Serie C No. 111.

I/A Court H. R., Case of the Mapiripan Massacre v. Colombia, Merits, Reparations and Costs, Judgment of September 15, 2005, Serie C No. 134.

I/A Court H. R., Case of the Moiwana Community v. Suriname, Preliminary Objections, Merits, Reparations and Costs, Judgment of June 15, 2005, Serie C No. 124.

I/A Court H. R., Case of the Serrano Cruz Sisters v. El Salvador, Preliminary Objections, Judgment of November 23, 2004, Serie C No. 118.

I/A Court H. R., The Right to Information on Consular Assistance. In the Framework of the Guarantees of the due Process of Law, Advisory Opinion OC-16/99 of October 1, 1999.

I/A Court H. R., Case of the Saramaka Indigenous Community v. Suriname, Preliminary Exceptions, Merits, Reparations and Costs, Judgment of August 12, 2008, Serie C No. 185.

I/A Court H. R., Case of the Sarayaku Indigenous Community v. Ecuador, Merits, and Reparations, Judgment of June 27, 2012, Serie C No. 245. 
I/A Court H. R., Case of the Sawhoyamaxa Indigenous Community v. Paraguay, Merits, Reparations and Costs, Judgment of March 29, 2006, Serie C No. 146.

I/A Court H. R., Case of the Yakye Axa Indigenous Community v. Paraguay, Merits, Reparations and Costs, Judgment of June 17, 2005, Serie C No. 125.

I/A Court H. R., Hilaire, Constantine and Benjamin and others v. Trinidad and Tobago, Judgments, Merits, Reparations and Costs, Judgment, 21 June 2002, IACTHR, Serie C No. 94.

I/A Court H. R., Rights of migrant children in the context of migration and/ or in need of international protection, Advisory Opinion OC-21/14 of August 19, 2014, Serie A No. 21.

I/A Court H. R., The Right to Information on Consular Assistance. In the Framework of the Guarantees of the due Process of Law, Advisory Opinion OC-16/99 of October 1, 1999, Serie A No. 16.

Island of Palmas Case (Netherlands, United States), 2 R. Int'l Arb., Awards 831. Korea - Measures Affecting Government Procurement (19 January 2000), WT/DS163/R, para. 7.96.

Legal Consequences for States of the Continued Presence of South Africa in Namibia (South West Africa) notwithstanding Security Council Resolution 276 (1970), ICJ Reports 1971.

S. S. Wimbledon, PCI, Serie A No. 1.

The Effect of Reservations on the Entry into Force of the American Convention on Human Rights, Advisory Opinion OC-2/82, Serie A No. 2, 1982.

The Right to Information on Consular Assistance in the Framework of the Guarantees of the Due Process of Law, Advisory Opinion OC-16/99 of October 1, 1999, Serie A No. 16.

Tyrer v. The United Kingdom, ECtHR, 1978, Serie A No. 26.

Young Loan Arbitration (Belgium, France, Switzerland, United Kingdom and United States/ Germany), 59 ILR 494 (1980).

\section{Articles}

Boisson de Chazournes, L., Subsequent Practice, Practices and "Family-Resemblance", Towards embedding Subsequent Practice in its Operative Milieu - A Multi-Actor Perspective, IRPA Working Paper, GAL Series No. 1/2013.

Elias, T. O., "The Doctrine of Intertemporal Law", 74 Am. J. Int'l L., 285 (1980). 
Haraszti, G., Some Fundamental Problems in the Law of Treaties, Akadémiai Kiadó, Budapest, 1973, p. 18.

Helmersen, S., "Evolutive Treaty Interpretation: Legality, Semantics and Distinctions", EJLS, 2013, 6, (I).

Higgins, R., "A Babel of judicial voices? Ruminations from the bench", International and Comparative Law Quarterly, 2006, 55.

McLachlan, C., "The principle of Systematic Integration and Article 31 (3) (c) of the Vienna Convention", International and Comparative Law Quarterly, 2005, 54, p. 280. ICLQ vol. 54, April 2005.

Simma, B. \& Puylkowski, D., "Of Planets and the Universe: Self-contained Regimes in International Law”, 17 EJIL 2006.

\section{Books}

Annuaire de l'nstitute de droit international, 1956, 46.

Aust, A., Modern Treaty Law and Practice, Oxford University Press, 2013.

Burguogue, A., The Inter-American Court of Human Rights, Oxford, 2011.

Gardiner, R., Treaty Interpretation, Oxford University Press, Oxford, 2008.

Lauterpacht, H., The Function of Law in the International Community, Oxford University Press, 1933.

Sinclair, I., The Vienna Convention on the Law of Treaties.

Thirlway, H. W. A., International Customary Law and Codification, Sijthoff, Leiden, 1972.

Watts, A., Pronto, A. \& Wood, M., The International Law Commission 19992009, volume IV. Treaties, Final Draft Articles, and Other Materials, Oxford University Press, 2010.

\section{Book chapters}

Brownlie, I., "The Rights of Peoples in Modem International Law", in Crawford, J. (ed.), The Rights of Peoples, Clarendon Press, Oxford, 1988.

Bollecker, B., «L'Avis Consultatif du 21 Juin 1971 dnas l'affaire de la Namibie (Sud-Ouest Africain)», Annuaire Francais de Droit International, 1971, 17.

Caflisch, L. \& Cancado Trindade, A., "Les conventions americaine et européenne des droits de l'homme et le droit international général", 108 RGDIP vol. 108 (2004).

Ferrer Mac-Gregor, E., "Interpretación conforme y control difuso de convencionalidad. El nuevo paradigma para el juez mexicano”, en 
Carbonell, M. \& Salazar, P. (Coords.), La reforma constitucional de derechos humanos: un nuevo paradigma, México, Instituto de Investigaciones Jurídicas - UNAM, 2011.

Fox, H., "Article 31 (3) (a) and (b) of the Vienna Convention and the Kasikili/Sedulu Island Case", in Fitzmaurice, M., Treaty Interpretation and the Vienna Convention on the Law of Treaties.

Greenwood, S., "Unity and diversity in international law", in Andenas, M. \& Bjorge, E., A Farewell to Fragmentation, Cambridge University Press, 2015.

Letsas, G., "The Truth in Autonomous concepts: How to Interpret the ECHR", EJIL, 2004, 2.

Pinto, M., "El principio pro homine. Criterios de hermenéutica y pautas para la regulación de los derechos humanos", en La aplicación de los tratados de derechos humanos por los tribunales locales, Centro de Estudios Legales y Sociales (CELS), Buenos Aires, Editorial del Puerto, 1997.

Salvioli, S., "Un análisis desde el principio pro persona sobre el valor jurídico de las decisiones de la Comisión Interamericana de Derechos Humanos", en En defensa de la Constitución: libro homenaje a Germán Bidart Campos, Ediar, Buenos Aires, 2003, pp. 143-155.

Sheeran, S., "The Relationship of international human rights law and general international law: hermeneutic constraint, or pushing the boundaries?", in Sheeran, S. \& Rodley, N., Routledge Handbook of International Human Rights Law, 2013.

Villiger, M., "The Rules on Interpretation: Misgivings, Misunderstandings, Miscarriage? The 'Crucible' Intended by the International Law Commission", in Canizzaro, E., The Law of Treaties Beyond the Vienna Convention, Oxford University Press, 2011.

Wachsmann, P., «Les methodes de l'intérpretation des conventions à la protection des droits de l'homme», in SFDI, La protection des droits de l'homme et l'évolution du droit international, Coll. 1998, Pedone, Paris, 1998. 
